ARAÚJO, LM; NEVES, LG; SOUSA, DA; ZEVIANI, WM; SILVA, LR; MAROSTEGA, TN. 2019. Biochemical descriptors: importance of the genetic divergence study in peppers. Horticultura Brasileira 37: 210-214. DOI - http://dx.doi.org/10.1590/S0102-053620190212

\title{
Biochemical descriptors: importance of the genetic divergence study in peppers
}

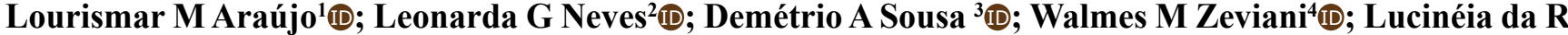 \\ Silva' ${ }^{2}$; Thalita N Marostega ${ }^{2} \mathbb{D}$
}

${ }^{1}$ Instituto Federal de Educação Ciência e Tecnologia de Mato Grosso (IFMT), Juína-MT, Brazil; lourismar.araujo@jna.ifmt.edu.br (correspondence author); ${ }^{2}$ Universidade Estadual de Mato Grosso (UNEMAT), Cáceres- MT, Brazil; ${ }^{3}$ Instituto Federal de Educação Ciência e Tecnologia de Mato Grosso (IFMT), Cáceres-MT, Brazil; ${ }^{4}$ Universidade Federal do Paraná (UFPR), Curitiba-PR, Brazil

\begin{abstract}
The genetic diversity of pepper genotypes is usually evaluated based on morphological and molecular descriptors. However, studies using biochemical descriptors of peppers are still incipient. Thus, the objective of this study was identify biochemical descriptors of Capsicum spp. with antioxidant action, most responsive to the selection of superior genotypes, and evaluate the correlation between concentrations of the parameters using principal components analysis. The experiment was conducted in the city of Cáceres, southwest Mato Grosso, Brazil. Seventy-eight pepper accessions from the Active Germplasm Bank of UNEMAT were planted in randomized block design. The harvested fruits were immersed in liquid nitrogen for two minutes, and the following biochemical analyses were performed: titratable acidity, ascorbic acid, total phenols, flavonoids, anthocyanins, carotenoids, chlorophyll a, chlorophyll b, and antioxidant activity. Biochemical descriptors that best estimated the genetic variability of the accessions were flavonoids, total phenols, chlorophyll $\mathrm{a}$, and ascorbic acid. Chlorophyll a and chlorophyll $\mathrm{b}$ were the compounds that showed the highest degree of correlation. Except chlorophyll a with ascorbic acid, all other vectors showed correlation ranging from moderate to strong.
\end{abstract}

Keywords: Capsicum spp., main components, genetic variability.

\section{RESUMO}

Descritores bioquímicos: importância no estudo da divergência genética em pimentas

A diversidade genética de genótipos de pimentas é comumente avaliada com base em descritores morfológicos e moleculares, no entanto, estudos empregando descritores bioquímicos em pimenta ainda são incipientes. Dessa forma, o objetivo deste trabalho foi identificar em Capsicum spp. os descritores bioquímicos com ação antioxidante mais responsivos à seleção de genótipos superiores, e avaliar a correlação entre a concentração dos parâmetros avaliados utilizando como ferramenta a análise de componentes principais. O experimento foi realizado no município de Cáceres, localizado na região sudoeste de Mato Grosso. Foram plantados 78 acessos de pimentas do BAG da UNEMAT em delineamento blocos ao acaso. Os frutos colhidos foram imersos em nitrogênio líquido por $2 \mathrm{~min}$, e em seguida realizadas as seguintes análises bioquímicas: acidez titulável; ácido ascórbico; fenóis totais; flavonoides; antocianinas; carotenoides; clorofila a; clorofila b e atividade antioxidante. Os descritores bioquímicos que melhor estimaram a variabilidade genética dos acessos foram flavonoides, fenóis totais, clorofila a e ácido ascórbico. Clorofila a e clorofila $b$ foram os compostos que apresentaram maior grau de correlação. Com exceção de clorofila a com ácido ascórbico, todos os outros vetores apresentaram correlação entre eles variando de moderada a fortemente correlacionada.

Palavras-chave: Capsicum spp., componentes principais, variabilidade genética.

\section{Received on May 22, 2018; accepted on February 1 $1^{\text {st }}, 2019$}

$\mathrm{T}$ he genus Capsicum belongs to the Solanaceae family, including a highly diverse group of sweet and hot peppers, probably originated in the American continent (Lannes et al., 2007; Moscone et al., 2007).

Its fruits are appreciated for a pungent and characteristic flavor, being thus classified as condiments. A series of health benefits is related to pepper, including the ability to neutralize free radicals provided by varying concentrations of titratable acids, ascorbic acid, phenols, flavonoids, carotenoids, vitamins A, C and $\mathrm{E}$, tocopherols and anthocyanins. These compounds, even in small concentrations, may significantly affect the prevention of degenerative diseases, including cancer, cardiovascular diseases, cataracts and the functioning of the immune system (Howard et al., 2000; Reifschneider, 2000; Davis et al., 2007; Vera-Guzmán et al., 2017).
The concentration of these compounds in Capsicum may vary depending on genotype and fruit maturation, and are influenced by growth conditions, losses after processing due to high temperatures or light, and cultivation methods (Guil-Guerrero, 2006).

According to Cruz \& Carneiro (2006), one of the most used methods to estimate genetic diversity is the multivariate technique, a tool that enables 
combining various parameters contained in the experimental unit, allowing for the characterization of genotypes based on a set of descriptors. The data allows analyzing correlations between studied characteristics, summarizing a wide range of characteristics within a smaller biological characteristic, evaluating the importance of each trait, validating the elimination of characters with low contribution (in terms of variation), producing indices for grouping individuals, and grouping individuals with the highest degree of similarity (by visual examination of graphical dispersions within a two or three-dimensional space).

It is common to evaluate the genetic diversity of Capsicum accessions based on morphological and/or molecular descriptors. However, studies using biochemical descriptors in pepper are still incipient. Thus, the objective of this study was to identify Capsicum spp. biochemical descriptors with antioxidant action more responsive to the selection of superior genotypes and to evaluate the correlation between concentration of the evaluated parameters using principal component analysis.

\section{MATERIAL AND METHODS}

\section{Environmental conditions and experimental design}

The experiment was conducted in the city of Cáceres, southwest region of Mato Grosso State, Brazil (15'27'37'S, $57^{\circ} 00$ ' $48^{\prime}$ 'W, altitude $118 \mathrm{~m}$ ), from April to October 2014. The municipality is part of the South-Centre Mato Grosso mesoregion and the Alto Pantanal microregion. The climate of the region, according to Köppen is Aw, with mean annual temperatures of $26.3^{\circ} \mathrm{C}$ and mean annual precipitation of $1,300 \mathrm{~mm}$ (Neves et al., 2011). The Capsicum experimental field is located at the Plant Development Laboratory of UNEMAT, Cáceres campus. A total of 78 Capsicum spp. genotypes from AGB (Active Germplasm Bank) of UNEMAT were sown in 128-cell trays containing Plantmax $^{\circledR}$ commercial substrate. The seedlings were placed in a greenhouse with controlled temperature and humidity. Seedlings were transplanted to the experiment area with four definitive leaves.

Genotypes of Capsicum spp. were arranged in randomized block design with three replications and two plants per plot. Spacing was $0.8 \times 1.2 \mathrm{~m}$, between plants and rows respectively. The irrigation system was autocompensating micro-sprinklers.

The soil of the area is Plinthosol. Soil analysis was performed by the Soil Laboratory of IFMT, campus Cáceres, with the following attributes: clay $=337$ $\mathrm{g} \mathrm{kg}^{-1}$; silt $=145 \mathrm{~g} \mathrm{~kg}^{-1}$; sand $=617 \mathrm{~g} \mathrm{~kg}^{-1}$; O. $\mathrm{M}=14,0 \mathrm{~g} \mathrm{dm}^{-3} ; \mathrm{pH}=6,1 ; \mathrm{P}=10,7 \mathrm{mg}$ $\mathrm{dm}^{-3} ; \mathrm{K}^{+}=0,23 \mathrm{cmol}_{\mathrm{c}} \mathrm{dm}^{-3} ; \mathrm{Mg}=1,45$ $\mathrm{cmol}_{\mathrm{c}} \mathrm{dm}^{-3} ; \mathrm{Ca}=2,77^{\mathrm{cmol}} \mathrm{dm}^{-3} ; \mathrm{Al}^{3+}=$ $0,0 \mathrm{cmol}_{\mathrm{c}} \mathrm{dm}^{-3} ; \mathrm{CTC}=5,5 \mathrm{cmol}_{\mathrm{c}} \mathrm{dm}^{-3}$; $\mathrm{V}(\%)=81,7 \%$.

Soil correction was performed according to soil analysis using $\mathrm{CaCO}_{3}$. According to technical recommendations, the pre-planting fertilization per panting hole was $5 \mathrm{~g}$ of $\mathrm{N}, 20 \mathrm{~g}$ of $\mathrm{P}_{2} \mathrm{O}_{5}, 7 \mathrm{~g}$ of $\mathrm{K}_{2} \mathrm{O}, 0.5 \mathrm{~g}$ of $\mathrm{H}_{3} \mathrm{BO}_{3}$ and $2 \mathrm{~g}$ of $\mathrm{ZnSO}_{4}$. Nutrients were mixed in each planting hole and soaked with water prior to planting. Post-planting fertilization per planting hole was divided into post-planting 1 (2 g 20-05-20 applied in the first two weeks after transplantation), and post-planting 2 (from the $3^{\text {rd }}$ week on, $3 \mathrm{~g}$ 20-05-20), and early fruiting (weekly fertilization with $4 \mathrm{~g} \mathrm{12-12-24}$, and $3 \mathrm{~g} \mathrm{Ca}\left(\mathrm{NO}_{3}\right)_{2}$.

Collection and storage of fruits, obtaining samples

Peppers from 78 accessions of Capsicum from the AGB of UNEMAT were collected in the form of bulk, where fruits of all plants from the same accession, regardless of the block, were collected and mixed. Harvest was performed on October 2014 , when the fruits were mature, covered at least $70 \%$ by the final skin color. Approximately one kilogram of fresh fruits was collected per accession.

To remove heat and paralyze metabolic activities, the collected fruits were rapidly cooled during two seconds in liquid nitrogen. After this step, the frozen fruits were packed in polyethylene bags with proper identifications and stored in an ultrafreezer at $-80^{\circ} \mathrm{C}$ until the time of analysis.

\section{Biochemical analyses}

Biochemical analyses were performed in the laboratory of Plant Development of UNEMAT, from November 2014 to May 2015. They comprised of the following:

\section{Titratable acidity}

Fruits were divided into triplicates, seeds were removed and only the pulp was used. Acidity was determined by titration as described by IAL (2008) and the acid content was quantified using equation 1 :

Acidity (\%) $=\frac{\text { Vs } \times \text { N x Meq } \times 100}{P}$

Where $\mathrm{Vs}=$ volume spent on titration; $\mathrm{N}=$ normality of the sodium hydroxide solution; Meq= miliequivalence (amount of acid (g) that $1 \mathrm{~mL}$ of base solution can reduce); $\mathrm{P}=$ sample mass in grams.

\section{Ascorbic acid (vitamin C)}

The content of vitamin $\mathrm{C}$ was obtained from the precept of the ascorbic acid (AA) by Tillman's reagent by titration, according to Oliveira et al. (2010). This is based on the reduction of 2,6-dichlorophenol-indophenol staining by ascorbic acid.

To calculate the amount of AA present in the sample, equation 2 was applied:

$$
\mathrm{C}=\frac{\mathrm{P} \times \mathrm{C} \times 50}{\mathrm{~V} \times \mathrm{m}} \times 100
$$

Where $\mathrm{P}=$ volume $(\mathrm{mL})$ of AA standard solution spent; $\mathrm{C}=\mathrm{AA}$ concentration ( $\mathrm{mg} \mathrm{mL}^{-1}$ ) in the standardization of DCFI; $\mathrm{V}=$ volume $(\mathrm{mL})$ of sample extract used during titration; $\mathrm{m}=$ amount of sample used for extraction.

To not degrade ascorbic acid, all procedures were conducted under dim light.

\section{Total phenols}

Fruits were defrosted and seeds removed. Then, approximately $0.5-2 \mathrm{~g}$ of pulp was weighed and total phenols content was obtained as described by Swain \& Hills (1959).

Total phenolic content was calculated and expressed in mg of EGA (Equivalent to Gallic Acid)/100 $\mathrm{g}$ of fresh pulp.

The amount of total phenols (TP) was obtained by Equation 3: 


$$
\mathrm{Tp}=\frac{\left(\text { reading } \frac{\mathrm{mg} \mathrm{L}^{-1}}{10}\right)}{\text { sample weight }(\mathrm{g})}
$$

Where Reading $(750 \mathrm{~nm})=$ concentration of gallic acid obtained from the calibration curve referring to the absorbance read for the sample. The result was expressed in $\mathrm{mg}$ of EGA/100 g pulp.

\section{Flavonoids and anthocyanins}

The analysis of flavonoids and anthocyanins was performed according to Francis (1982). To determine the absorbance, a Biochrom pound UV/ Vis S80 digital spectrophotometer was used. Readings were taken at 374 and $535 \mathrm{~mm}$ wavelengths for flavonoids and anthocyanins, respectively. The "blank" solution was composed only of ethanol solution $95 \%+1.5 \mathrm{~N} \mathrm{HCl}(85: 15)(\mathrm{v} / \mathrm{v})$. Equation 4 (for calculating flavonoids)

$$
\mathrm{DF}=\frac{\text { Absorbance }(374 \mathrm{~nm}) \times \mathrm{FD}}{76.5}
$$

Equation 5 (for calculating anthocyanins):

$$
\mathrm{DA}=\frac{\text { Absorbance }(374 \mathrm{~nm}) \times \mathrm{FD}}{98.2}
$$

Where $\mathrm{DF}=$ determination of flavonoids; $\mathrm{DA}=$ determination of anthocyanins; 76.5 and 98.2 are correction factors for the formulas; $\mathrm{FD}=$ factor of dilution obtained using the weight of the sample (0.5) divided by the dilution volume (25 mL). Results were correlated to 1 $\mathrm{mL}$ (amount of gas in $1 \mathrm{~mL}$ solution), and the amount for $100 \mathrm{~g} \mathrm{~mL}^{-1}$ was determined. and $b$

The determination of total carotenoids and chlorophyll $\mathrm{a}$ and $\mathrm{b}$ were performed after dimethylsulfoxide (DMSO) extraction, according to the method proposed by Wellburn (1944). Equation 6 (for calculating the chlorophyll a):

[Chlorophyll a] $\left(\mathrm{mg} \mathrm{L}^{-1}\right)=12.19$ $\mathrm{x}$ Absorbance (665 nm) - $3.45 \mathrm{x}$ Absorbance (649 nm)

Equation 7 (for calculating the chlorophyll b):

[Chlorophyll b] $\left(\mathrm{mg} \mathrm{L}^{-1}\right)=21.99$ x Absorbance $(649 \mathrm{~nm})-5.32 \mathrm{x}$ Absorbance (665 nm)

Equation 8 (for calculating carotenoids):

$$
\begin{aligned}
& \mathrm{C}=[1,000 \times \text { Abs }(2.14 \times \text { Chlor.a - } \\
& 70.16 \text { x Chlor.b)] / } 220
\end{aligned}
$$

Where $\mathrm{C}=$ carotenoids $\left(\mathrm{mg} \mathrm{L}^{-1}\right)$; $\mathrm{Abs}=$ absorbance; Chlor.a = concentration of chlorophyll a by Equation 6; Chlor. $b=$ concentration of chlorophyll $b$ by Equation 7.

\section{Total antioxidant activity}

The total antioxidant activity was obtained, according to the methodology proposed by Rufino et al. (2007).

For the selection of the most relevant biochemical descriptors, Principal Component Analysis (PCA) was used. It was processed with the correlation matrix $(\mathrm{R})$ of the original variables. The eigenvalues that formed the eigenvectors were obtained, showing the degree of correlation between the biochemical compounds studied.

\section{RESULTS AND DISCUSSION}

The analysis showed that the first two principal components explained $62.47 \%$ of variances contained in the original variables. If added to the third component, this value increases to $75.26 \%$; if added to the fourth component, it increased to $84.75 \%$ (Table 1). When this limit was not reached in the first two components, the analysis is complemented by graphic dispersion in relation to the third and fourth components (Cruz \& Carneiro, 2006).

For the first principal component (PC1), the greatest contribution of descriptors in discriminating genotypes were flavonoids (FLAV), carotenoids
(CAROT) and total phenols (TP). For the second principal component (PC2), the main descriptors influencing the formation of the component were chlorophyll a (CHLOR a), chlorophyll $\mathrm{b}$ (CHLOR b) and antioxidant activity (ACT) (Table 2).

For the third component (PC3), ascorbic acid (AA), anthocyanins (ANTHO) and carotenoids (CAROT) were the descriptors that most influenced the component's formation. For the fourth component (PC4), the most important descriptors were titratable acidity (TA), AA and ACT. The relative importance of a $\mathrm{PC}$ is evaluated by the percentage of variance that it explains, i.e., the proportion of the total variance explained, in this case until PC4, which was $84.75 \%$ of the total variation, an index sufficient to explain a great part of the variation without the need to proceed to the analysis of the other principal components.

The International Plant Genetic Resources Institute (IPGRI) proposes the descriptors to be used in Capsicum studies. However, only a few descriptors characterize the biochemical variables of the fruits (IPGRI, 1995). These characteristics can be further explored in genetic diversity studies and can contribute to the selection of genotypes desired for different purposes.

In some studies, when the number of descriptors is very large, it is necessary to discard those of little importance in the discrimination of the evaluated material, reducing work force, time and cost spent on the analysis and interpretation of experimental data.

Table 1. Estimation of eigenvalues associated with main components, relative (\%) and cumulative importance related to nine biochemical descriptors evaluated in fruits of 78 Capsicum spp. genotypes. Cáceres, UNEMAT, 2015.

\begin{tabular}{lccc}
\hline Components & Eigenvalues & Value (\%) & Accumulated (\%) \\
\hline 1 & 2.062 & 47.12 & 47.12 \\
2 & 1.170 & 15.22 & 62.47 \\
3 & 1.072 & 12.78 & 75.26 \\
4 & 0.924 & 9.48 & 84.75 \\
5 & 0.678 & 5.11 & 89.87 \\
6 & 0.581 & 3.75 & 93.62 \\
7 & 0.520 & 3.00 & 96.63 \\
8 & 0.494 & 2.71 & 99.35 \\
9 & 0.241 & 0.64 & 100.00 \\
\hline
\end{tabular}


Based on the principle that the relative importance of main components decreases from the first to the last, it can be said that the last components are responsible for explaining a minimum fraction of the total variance available. Thus, the variable that has the highest weighting coefficient for the lowest eigenvalue component is considered less important in explaining the genetic variability of the studied material. It can therefore be discarded. This parameter has been commonly used to discard the characteristic with the highest coefficient from the last component, keeping whose eigenvalue (Table 1) does not exceed 0.7 (Cruz et al., 2004).

Following the criteria proposed above, the descriptors that least explained the total variance were CHLORb, ANTHO, CAROT, TA and ACT. These descriptors had higher weighting coefficients in the last components and may therefore be dismissed when performing dissimilarity analyses. This can be done due to the high degree of correlation between these descriptors and the others used in the study. Thus, the descriptors TP, FLAV, CHLORa and AA were the most responsive to the selection of Capsicum spp. genotypes.

\section{Correlation between vectors}

As reported by Smith et al. (2002), interpretations can be made in function of the angle between vectors. If an angle is close to zero, the correlation is very high and positive; if it is close to $180^{\circ}$, the correlation is also high, but negative; finally, if the angle is approximately $90^{\circ}$, the variables are little related.

As seen in Figure 1, the compounds
CHLORa and CHLORb are strongly correlated. In fact, the production of one is conditioned to the production of the other, which explains its high correlation (Lichtenthaler et al., 1986).

Similarly, the ANTHO content is strongly correlated with the FLAV content. According to Taiz \& Zeiger (2013), anthocyanins, flavones, flavonoids and isoflavones are subgroups of flavonoids; in turn, ANTHOs belong to the group of pigmented FLAVs, being responsible for the production of most of the red, pink, purple and blue colors seen in flowers and fruits. This explains the strong correlation between ANTHO and FLAV, because ANTHOs are molecules that compose the group of total flavonoids.

Other strongly correlated compounds

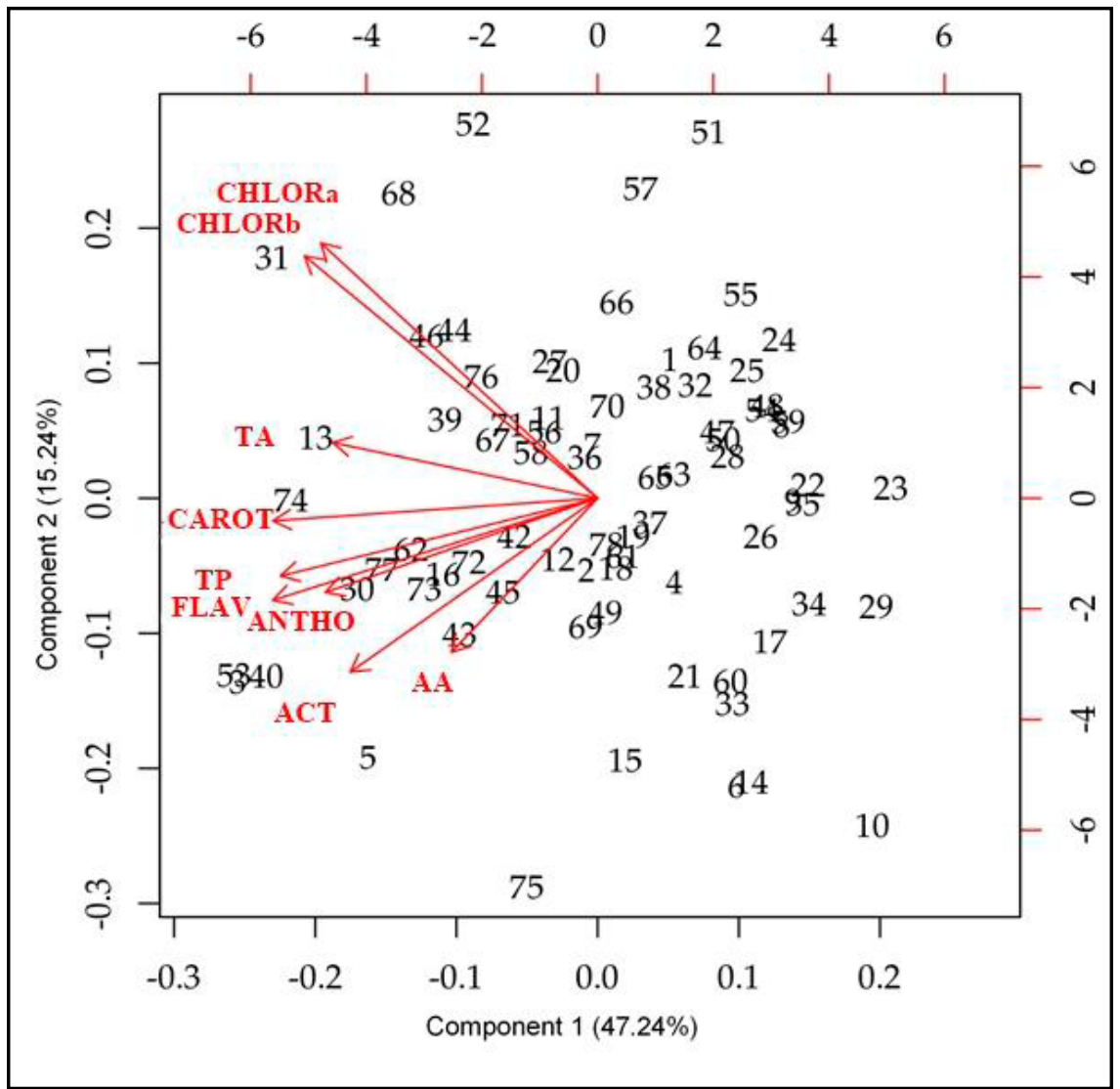

Figure 1. Biplot projection of variables chlorophyll a (CHLORa), chlorophyll b (CHLORb), titratable acidity (TA), total carotenoids (CAROT), total phenols (TP), flavonoids (FLAV), anthocyanins (ANTHO), antioxidant activity (ACT) and ascorbic acid (AA), in the plane defined by PC1 and PC2 in fruits of 78 Capsicum spp genotypes. Cáceres, UNEMAT, 2015.

Table 2. Weighting coefficient of nine biochemical descriptors evaluated in fruits of 78 Capsicum spp. genotypes. Cáceres, UNEMAT, 2015.

\begin{tabular}{lccccccccc}
\hline WC & TA $^{1}$ & AA & TP & FLAV & ANTHO & CHLORa & CHLORb & CAROT & ACT \\
\hline 1 & -0.316 & -0.174 & -0.378 & -0.387 & -0.325 & -0.330 & -0.350 & -0.387 & -0.295 \\
2 & 0.122 & -0.338 & -0.170 & -0.224 & -0.207 & 0.561 & 0.532 & -0.049 & -0.382 \\
3 & 0.202 & 0.538 & 0.216 & -0.279 & -0.509 & 0.080 & 0.164 & -0.378 & 0.328 \\
4 & 0.658 & 0.606 & 0.125 & 0.001 & -0.185 & -0.232 & -0.152 & -0.086 & 0.251 \\
5 & -0.028 & -0.056 & -0.611 & -0.284 & 0.308 & 0.144 & 0.085 & -0.021 & $\mathbf{0 . 6 4 7}$ \\
6 & $\mathbf{0 . 6 1 6}$ & 0.408 & -0.413 & 0.102 & 0.272 & -0.040 & $-0.122-$ & -0.169 & -0.393 \\
7 & 0.164 & 0.154 & -0.031 & -0.539 & -0.150 & -0.227 & 0.004 & $\mathbf{0 . 7 5 7}$ & -0.099 \\
8 & -0.031 & 0.058 & -0.464 & 0.577 & $\mathbf{- 0 . 5 9 7}$ & -0.005 & 0.016 & 0.281 & 0.111 \\
9 & 0.044 & 0.012 & 0.068 & -0.082 & -0.096 & 0.664 & $\mathbf{- 0 . 7 2 2}$ & 0.120 & 0.027 \\
\hline
\end{tabular}

$\mathrm{WC}=$ Weighting coefficient; $\mathrm{TA}=$ titratable acidity; $\mathrm{AA}=$ ascorbic acid $\left(\mathrm{mg} \mathrm{L}^{-1}\right) ; \mathrm{TP}=$ total phenols; $\mathrm{FLAV}=$ flavonoids; $\mathrm{ANTHO}=$ anthocyanins; $\mathrm{CHLORa}=$ chlorophyll $\mathrm{a} ; \mathrm{CHLOR} \mathrm{b}=$ chlorophyll $\mathrm{b} ; \mathrm{CAROT}=$ total carotenoids; $\mathrm{ACT}=$ antioxidant activity. 
are TP and FLAV. According to Sousa et al. (2007), phenolic compounds are distributed in the following categories: simple phenols, phenolic acids, coumarins, flavonoids, stilbenes, condensed and hydrolysable tannins, lignans and lignins. Thus, in a manner analogous to that described in the previous paragraph, FLAVs are inserted into the total phenols group. Thus, the correlation between the increase and the decrease of the concentration of both is clearly justified.

The antioxidant activity is positively correlated with all other variables, ranging from a strong to a weak correlation for CHLORa, CHLORb, TA, CAROT, TP, FLAV, ANTHO and $\mathrm{AA}$, and the latter presented the highest correlation with ACT. These data are easily explained by different authors by attributing the neutralizing capacity of free radicals to all these compounds, so that ACT is the result of the sum of the neutralizing capacity of free radicals shown by all these antioxidant compounds together (Costa et al., 2010; Vieira et al., 2011; Moraes et al., 2012; Gomez \& Ochoa, 2013; Carvalho et al., 2014).

The not correlated compounds were only CHLORa and AA. That is, the increase or decrease of these compounds did not positively or negatively change the concentration of the others. The lowest correlation was found between $\mathrm{CHLORb}$ and AA.

Biochemical descriptors that contributed the most to estimate the genetic variability among accessions, through main components analyses, were Flavonoids, Total Phenols, Chlorophyll a and Ascorbic Acid. The descriptors that less explained the total variance available were Chlorophyll $b$, Anthocyanins, Carotenoids, Titrable Acidity and Antioxidant Activity. They can therefore be discarded. Except for Chlorophyll a with Ascorbic Acid, all other vectors had a moderate to strong correlation between them. The variables Chlorophyll a and Chlorophyll $b$ had the highest correlation degree vectors.

\section{REFERENCES}

CARVALHO, AV; MATTIETTO, RA; RIOS,
AO; MORESCO, KS. 2014. Mudanças nos compostos bioativos e atividade antioxidante de pimentas da região amazônica. Pesquisa Agropecuária Tropical 44: 399-408.

COSTA, LM; MOURA, NF; MARANGONI, C; MENDES, CE; TEIXEIRA, AO. 2010. Atividade antioxidante de pimentas do gênero Capsicum. Ciência e Tecnologia de Alimentos 30: 51-59.

CRUZ, CD; CARNEIRO, PCS.2006. Modelos biométricos aplicados ao melhoramento genético. Viçosa: UFV. 585p.

CRUZ, CD; REGAZZI, AJ; CARNEIRO, PCS. 2004. Modelos biométricos aplicados ao melhoramento genético. Viçosa: UFV. 668p.

DAVIS, CB; MARKEY, CE; BUSCH, MA; BUSCH, KW. 2007. Determination of capsaicinoids in Habanero peppers by chemometric analysis of UV spectral data. Journal of Agricultural and Food Chemistry 55: 5925-5933.

FRANCIS, FJ. 1982. Analysis of anthocyanins. In: MARKAKIS, P. Anthocyanins as food colors. New York: Academic Press. p.181-207.

GÓMEZ-GARCIA, MR; OCHOA-ALEJO, N. 2013. Biochemistry and molecular biology of carotenoid biosynthesis in chili peppers (Capsicum spp.). International Journal of Molecular Sciences 14: 19025-19053.

GUIL-GUERRERO, JL; MARTÍNEZGUIRADO, C; REBOLLOSO-FUENTES, MM; CARRIQUE-PÉREZ, A. 2006. Nutrient composition and antioxidant activity of 10 peppers. European Food Reserch and Technology 224: 1-9.

HOWARD, LR; TALCOTT, ST; BRENES, CH; VILlALON, B. 2000. Changes in phytochemical and antioxidant activity of selected pepper cultivars (Capsicum spp.) as influenced by maturity. Journal of Agricultural and Food Chemistry 48: 1713-1720.

IAL - Instituto Adolfo Lutz. 2008. Normas Analíticas do Instituto Adolfo Lutz. Métodos químicos e físicos para análise de alimentos. São Paulo: Digital. 1020p.

IPGRI - International Plant Genetic Resources Institute, Renamed Bioversity International. 1995. Descriptors for Capsicum (Capsicum spp.). Rome: International Plant Genetic Resources Institute.132p.

LANNES, SD; FINGER, FL; SCHUELTER, AR; CASALI, VWD. 2007. Growth and quality of Brazilian accessions of Capsicum chinense fruits. Scientia Horticulturae 112: 266-270.

LICHTENTHALER, HK; BUSCHMANN, C; RINDERLE, U; SCHMUCK, G. 1986. Application of chlorophyll fluorescence in ecophysiology. Radiation and Environmental Biophysics 25: 297-308.

MORAES, LP; PAZ, MF; ARGANDONA, EJS; SILVA, LR; ZAGO, TO. 2012. Phenolic compounds and antioxidant activity of fermented "Dedo-de-moça" pepper sauce. Biochemistry and Biotechnology Reports 1: 33-38.

MOSCONE, EA; SCALDAFERRO, MA; GRABIELE, M; CECCHINI, NM; GARCÍA SÁNCHES, Y; JARRET, R; DAVIÑA,
JR; DUCASSE, DA; BARBOZA, GE; EHRENDORFER, F. 2007. The evolution of chili peppers (Capsicum - Solanaceae): a cytogenetic perspective. Acta Horticulturae 745: 137-169.

NEVES, SMAS; NUNES, MCM; NEVES, NJ. 2011 Caracterização das condições climáticas de Cáceres-MT-Brasil, no período de 1971 a 2009: subsídio às atividades agropecuárias e turísticas municipais. Boletim Goiano de Geografia 31: 55-68.

OLIVEIRA, RG; GODOY, HT; PRADO, MA. 2010. Otimização de metodologia colorimétrica para a determinação de ácido ascórbico em geleias de frutas. Ciência e Tecnologia de Alimentos 30: 244-249.

REIFSCHNEIDER, FJB. 2000. Capsicum: pimentas e pimentões. Brasília: Embrapa Comunicação para Transferência de Tecnologia. 113p.

RUFINO, MSM; ALVES, RE; BRITO, ES; MORAIS, SM; SAMPAIO, CG; PÉREZJIMÉNEZ, J; SAURA-CALIXTO, FD. 2007. Determinação da atividade antioxidante total em frutas pela captura do radical livre DPPH. Fortaleza: Embrapa Agroindústria Tropical. 4p. (Comunicado Técnico 127).

SMITH, RR; MOREIRA, VL; LATRILLE, LL. 2002. Characterization of dairy productive systems in the Tenth Region of Chile using multivariate analysis. Agricultura Técnica 62: 35-395.

SOUZA, CMMDE; SILVA, HRE; VIEIRA JUNIOR, GM; AYRES, MCC; COSTA, CLSDA; ARAÚJO, DS; CAVALCANTE, LCD; BARROS, EDS; ARAÚJO, PBDEM; BRANDÃO, MS; CHAVES, MH. 2007. Fenóis totais e atividade antioxidante de cinco plantas medicinais. Química Nova 30: 351-355.

SWAIN, T; HILLS, WE. 1959. The phenolic constituents of Punnus domestica. I. - The quantitative analysis of phenolic constituents. Journal of the Science of Food and Agriculture 19: 63-68.

TAIZ, L; ZEIGER, E. 2013. Fisiologia vegetal. Porto Alegre: Art Med. 918p.

VERA-GUZMÁN, AM; AQUINO-BOLAÑOS, EM; HEREDIA-GARCÍA, E; CARRILLORODRÍGUEZ, JC; HERNÁNDEZDELGADO, S; CHÁVEZ-SERVIA, JL. 2017. Flavonoid and capsaicinoid contents and consumption of mexican chili pepper (Capsicum annuum L.) Landraces. In: JUSTINO, GC (eds). Flavonoids - from biosynthesis to human health. IntechOpen. p. 405-437.

VIEIRA, LM; SOUSA, MSB; MANCINIFILHO, J; LIMA, A. 2011. Fenólicos totais e capacidade antioxidante in vitro de polpas de frutos tropicais. Revista Brasileira de Fruticultura 33: 888-897.

WELLBURN, AR. 1994. The spectral determination of chlorophylls $a$ and $b$, as well as total carotenoids, using various solvents with spectrophotometers of different resolution. Journal Plant Physiology 144: 307-313. 